\title{
Engineering and Human Rights: Teaching Across the Divide
}

\author{
Shareen HERTEL* and Allison MacKAY**
}

Keywords: Global Compact, labour rights auditing, life cycle assessement (LCA)

College students are among the world's most avid consumers of new technologies, innovative products, and cutting-edge arts and entertainment. Young people increasingly view ethical consumption as a way to express their politics in action. ${ }^{1}$ Yet they are often unaware of the full social and environmental impact of many of the products and services they consume. ${ }^{2}$ The few who are attuned to such issues frequently lack the technical skills for cross-disciplinary analysis of contemporary business challenges both in terms of human rights and sustainability. Students are typically trained either in the science, technology, engineering, and mathematics (STEM) fields, or in the social sciences and humanities, but not in both. ${ }^{3}$

This article explores a vehicle for closing the gap: an undergraduate seminar that explicitly integrates students from the STEM fields within an existing human rights minor curriculum at the University of Connecticut. ${ }^{4}$ Our seminar on

* Associate Professor of Political Science and Human Rights at the University of Connecticut.

** Professor of Civil, Environmental and Geodetic Engineering at The Ohio State University, USA.

1 Melissa R Gotlieb and Chris Wells, 'From Concerned Shopper to Dutiful Citizen: Implications of Individual and Collective Orientations toward Political Consumerism' (2012) 644 Annals of the American Academy of Political and Social Science 207, see especially 209.

2 Shakuntala Banaji and David Buckingham, 'The Civic Sell: Young People, the Internet, and Ethical Consumption' (2009) 12 Information, Communication and Society 1197, see especially 1200.

3 McCahon and Lavelle analyse the trend toward integration of engineering and business curricula around total quality management but do not consider integration of human rights; see Cynthia S McCahon and Jerome Lavelle, 'Implementation of Cross-disciplinary Teams of Business and Engineering Students for Quality Improvement Projects' (2010) 73 Journal of Education for Business 150. The syllabus archive maintained by the Science and Human Rights Coalition of the American Academy for the Advancement of Science lists only one course that integrates engineering and human rights explicitly, http://www.aaas.org/page/syllabi-science-and-human-rights\#Engineering (accessed 11 May 2015). Recently, members of the Columbia University Teaching Business and Human Rights Forum (a consortium of 200 professors from 120 institutions in 30 countries) invited the authors of this article to present an April 2015 webinar on cross-disciplinary STEM/human rights teaching in light of the paucity of instruction of this type. See https://web.law. columbia.edu/sso/passcode-login?destination=human-rights-institute/initiatives/global-economy/teaching-businesshuman-rights (accessed 11 May 2015).

4 At the time we developed this course jointly, both authors were faculty members at the University of Connecticut. MacKay has since relocated to The Ohio State University, but the course analysed in this article is well-suited to team teaching through an online format. 
'Assessment for Human Rights \& Sustainability' is central to an emerging track of courses at the University of Connecticut that equip students from the STEM fields along with students from the social sciences and humanities to work together to understand the social and environmental limits that constrain contemporary business. ${ }^{5}$

The course we have developed exposes students to the core concepts of human rights and sustainability in global supply chains. It not only acquaints students with the potentially negative impact that business activities can have on people and the environment, but also enables students to explore ways to 're-engineer' design and production processes to render them more socially and environmentally sustainable. The course familiarizes students with the legal and normative foundations of human rights theory along with the scientific concepts and fundamental elements of sustainability theory. We focus empirically on a broad range of legal and voluntary standards for labour and environmental compliance, along with sectoral and firm-level strategies for implementation. Sectors targeted for analysis in the class involve engineeringintensive business practices including construction, electronics manufacturing, and biofuel production.

During the course, we develop our students' ability to work in interdisciplinary teams (engineers and non-engineers) by tasking groups with assessing the actual reporting of companies that are members of the United Nations Global Compact. Each team produces an integrated assessment of one company's practices and embeds their research within a broader contextual analysis of the regulatory framework and the political as well as social and historical legacies of the home and host countries where firms operate. The course also explores trends in innovation within the sector and in stakeholder communities connected to these firms. Case study-based instruction is central to business school curriculum. ${ }^{6}$ We have adapted this form of pedagogy for use in cross-disciplinary teaching that bridges the human rights and engineering fields. ${ }^{7}$

We involve professionals in the fields of human rights auditing and supply chain management in our seminar as guest speakers. The aim is to expose our students to the practical application of the ideas we are exploring in class. Interaction with both engineering and non-engineering professionals (often alumni) offers our students a vision of how they could develop a career that builds on the knowledge gained in this course. As one of our guest speakers explained to our students, had she been told 20 years ago (when she was majoring in German and Economics at the University of Connecticut) that she would some day guest lecture for a class in the School of Engineering, she would have laughed. Today, as the director of global labour rights for a Fortune 100 firm, she views courses like this one as being on the cutting edge of interdisciplinary education in business and human rights.

\footnotetext{
5 For details on this initiative, see announcements from the University of Connecticut School of Engineering, http://news.engr.uconn.edu/human-rights-institute-and-engineering-team-to-offer-human-rights-minor.php (accessed 13 August 2015) and the University of Connecticut Human Rights Institute, http://humanrights.uconn.edu/2014/09/24/laborrights-in-focus/ (accessed 12 August 2015). For an interview with the authors regarding this course, see http://today.uconn. edu/blog/2014/12/the-social-impact-of-engineering/ (accessed 13 August 2015).

6 Mark C Baetz and David J Sharp, 'Integrating Ethics Content into the Core Business Curriculum: Do Core Teaching Materials Do the Job?' (2004) 51 Journal of Business Ethics 53.

7 For additional resources, see case study resources available from the UN Global Compact, https://www. unglobalcompact.org/issues/human_rights/business_practice.html (accessed 11 May 2015).
} 


\section{Pedagogy}

Teaching a course of this nature is naturally an intellectual stretch for the students and faculty alike. Our strategy has been threefold:

1. Know theory: Ground ourselves and our students in foundational concepts in each field;

2. Assess practice: Cultivate students' ability to critically assess varying approaches to regulation and practical implementation of human rights and environmental standards; and

3. Learn by doing: Develop students' ability to work across disciplines and in teams in order to prepare them for work in a rapidly evolving professional field.

In our first semester teaching this course together, two-thirds of our 16 students and one auditor were engineers, and one-third were students from the social sciences and humanities who were double-majoring, or completing a minor, in human rights. Our three-hour per week course format allowed for lectures and group-based work. The first nine weeks of the 14-week semester involve a combination of presentations and Socratic discussion aimed at drawing out the main themes of the classics in our respective cannons-for example, Richard Locke's work on supply chain management ${ }^{8}$ and Gro Harlem Bruntland's on sustainability. ${ }^{9}$ Students also read more specialized scholarship that highlights concepts such as industrial ecology, ${ }^{10}$ eco-efficiency in waste management and closed loop manufacturing, ${ }^{11}$ and social upgrading in production. ${ }^{12}$ Central concepts for the course include life cycle analysis ${ }^{13}$ and the Deming cycle or 'Plan-Do-Check-Act' framework for supply chain management. ${ }^{14}$

We equip non-STEM students with the tools to understand environmentally-generated limits to consumption. ${ }^{15}$ At the same time, we familiarize engineers with the basic

\footnotetext{
8 Richard M Locke, The Promise and Limits of Private Power: Promoting Labor Standards in a Global Economy (Cambridge: Cambridge University Press, 2013).

9 Gro Harlem Brundtland, Our Common Future (New York: UN Commission on Environment and Development, 1987).

10 Lynn W Jelinski, Thomas E Graedel, Robert A Laudise, David W McCall, and C Kumar N Patel, 'Industrial Ecology: Concepts and Approaches' (1992) 89 Proceedings of the National Academy of Science 793.

11 Closed loop manufacturing incorporates returned products as part of the supply chain. John Ehrenfeld and Nicholas Gertler, 'Industrial Ecology in Practice: The Evolution of Interdependence at Kalundborg' (1997) 1 Journal of Industrial Ecology 51.

12 Social upgrading in production entails improving labour practices and skills development in tandem with productivity gains. Stephanie Barrientos, Gary Gereffi, and Arianna Rossi, 'Economic and Social Upgrading in Global Production Networks: A New Paradigm for a Changing World' (2011) 150 International Labour Review 319.

13 Life cycle analysis is a technique used to assess environment impact at all stages of a product's life, i.e., from 'cradle to grave'. Stephanie Hellweg and Llorenç Milà i Canals, 'Emerging Approaches, Challenges and Opportunities in Life Cycle Assessment' (2014) 6188 Science 1109.

14 The Deming cycle outlines a series of steps for planning, monitoring, and adjusting the production process in order to continuously improve goods or services. W Edwards Deming, The New Economics (Cambridge, MA: Massachusetts Institute of Technology-CASE, 1994).

15 John Rockström, Will Steffen, Kevin Noone, Åsa Persson, F Stuart Chapin III, Eric F Lambin, Timothy M Lenton, Marten Scheffer, Carl Folke, Hans Joachim Schellnhuber, Björn Nykvist, Cynthia A de Wit, Terry Hughes, Sander van der Leeuw, Henning Rodhe, Sverker Sörlin, Peter K Snyder, Robert Costanza, Uno Svedin, Malin Falkenmark, Louise Karlberg, Robert W Corell, Victoria J Fabry, James Hansen, Brian Walker, Diana Liverman, Katherine Richardson, Paul Crutzen, and Jonathan A Foley, 'A Safe Operating Space for Humanity' (2009) 461 Nature 472.
} 
normative standards that undergird modern supply chain management, such as United Nations treaties on human rights and labour standards along with the United Nations Global Compact and UN Guiding Principles on Business and Human Rights. We also translate the veritable alphabet soup of third-party certification for labour and environmental auditing (e.g., ISO standards, SA8000, LEED green auditing standards, and the G4 Sustainability Reporting Guidelines of the Global Reporting Initiative) into concrete thresholds for business action. We test students' knowledge through midterm and final exams that include identification of basic terms as well as responses to essay questions crafted around hypothetical business case scenarios.

The latter third of the course focuses on honing students' ability to identify the nature of business challenges, the options for regulation, adaptation, corrective action, and stakeholder relations in the context of case-study-based learning. We apply this pedagogical approach to cases in issue areas (such as e-waste and biofuels) that lend themselves to more technical discussions of constraints on resources in design and manufacturing as well as stakeholder dialogue in engineering intensive sectors. Finally, our team-based approach builds students' skills in firm-level analysis of compliance, reporting and design innovation while at the same time equipping them to work in fields that increasingly rely on team strategies to maximize efficiency and catalyse innovation.

The central assignment for our teams is to analyse the publicly-disclosed labour and environmental reporting of a selected United Nations Global Compact member firm ${ }^{16}$ alongside external reporting on the company (produced by governments and nongovernmental organizations as well as academics). Students develop an integrated assessment of the company's framework for managing human rights and environmental sustainability objectives, as well as current challenges facing the company in each area. They must employ the Deming cycle's 'Plan-Do-Act-Check' framework to explain whether the company: (i) relies on internal or external voluntary standards for performance benchmarks; (ii) employs specific metrics for assessing human rights and environmental impacts; and (iii) has systems in place for processing feedback to improve performance. Each team produces a ten-page written report and makes a ten-minute in-class oral presentation. Each team member is responsible for producing a specific section of the written report and the corresponding oral presentation. We assess team performance overall but assign individual grades to each team member based on the extent to which that person has embedded his or her analysis of a specific component of company performance within a larger policy framework and against the background of social and environmentally-generated limits to production.

\section{IMPLICATIONS}

As the field of business and human rights expands, courses like this will help equip the next generation of professionals to carry out complex assessment of the multiple factors

\footnotetext{
16 Companies selected by our students were: Microsoft (electronics); Unilever (consumer products); Monsanto (biotechnology); and Ford Motor (automotive). Notably, at least one of our students (a chemical engineer) had previously carried out a summer internship in one of these companies (i.e., Unilever) and the group presentation was considerably richer for the on-the-job insights of that student and the student's familiarity with the application of environmental standards in practice.
} 
(social and environmental) at stake in corporate activity. The importance of such training was highlighted by one guest speaker for our course, an engineer who directs companywide sustainability programmes at an industrial gas supply company. He noted that the task of addressing labour rights and environmental impacts has transitioned from ad hoc approaches to being ensconced in operations management within firms. By cross-training a new generation of professionals in both the human rights and engineering fields, we increase the potential for dynamic solutions to long-standing problems stemming from energy scarcity, under-development, and environmental stress. Students trained in this manner are better able to re-engineer processes to anticipate compliance problems and enhance efficiencies. They can more effectively engage stakeholders and report on adverse outcomes. And they can increase the sustainability and equity of business practices.

The course evaluations from students enrolled in this initial course offered ample evidence of impact, along with ideas for refinement. We obtained student feedback through an anonymous online survey administered by the University of Connecticut at the conclusion of the course. As instructors, we were evaluated separately and can only infer that students evaluating the engineering instructor (i.e., five for MacKay) tended to be engineers, and those evaluating the human rights instructor (i.e., eight for Hertel) tended to be human rights students. A large percentage ( 80 per cent) of those assumed to be engineers reported this course as being either 'about the same' level of difficulty or 'less' difficult than their other courses, whereas respondents assumed to be human rights students reported that this course was 'about the same' or 'more' difficult than their other courses in almost identical proportion ( 88 per cent). The different perceptions of difficulty may have stemmed from the inclusion of quantitative readings, which are often less familiar to human rights students than engineers. However, 80 per cent of the assumed engineering respondents reported that they had learned 'more' or 'much more' in this course than in their other courses; the same proportion reported that their desire to take this course was 'more' or 'much more' than for other courses. For the assumed non-engineering respondents, the proportion was 63 per cent across the same categories.

To us, these differences demonstrate an important demand-side effect related to bridging the human rights/STEM divide. Because engineering students have fewer opportunities within their curriculum for interdisciplinary exposure than human rights students, this type of course is potentially more attractive to engineers and the learning dividend more obvious. As one engineering student explained in open-ended responses to the evaluation survey:

This course was much more applicable to me as an Engineer than Phil[osophy] 1104 [Philosophy and Social Ethics] and I honestly think it should be the requirement instead. This course should fulfil another engineering elective or be a requirement for seniors. The environmental and human rights impacts we learned about helped me a lot on my senior design since we had to do ethical evaluations. Prior to this class, we never learned environmental impacts or supply chain management issues in engineering. I think it's very important to learn this information.

Another engineering student offered examples of 'more relevant' topics

such as how to ensure the metals you purchase to manufacture your electronics don't fund a civil war in the [Democratic Republic of the Congo] or use child labour in mines or looking at a company's duty and incentives to cutting down on their emissions/waste and reporting 
on those cuts transparently. Also a very good learning experience to do project group work with non-engineering majors in a higher level class [emphasis in the original].

Moving forward, a challenge for scholars and teachers of human rights will be to make clear to traditional social science, law, or humanities students the value of acquiring greater exposure to engineering-related business scenarios and technical tools in order to better analyse complex human rights and sustainability dilemmas. As one human rights student noted in evaluating our course: 'Personally, I don't think I will ever truly have to know this knowledge just for the sole fact that my career goals don't greatly involve this sector [i.e., engineering]. However, this class was really informative and I wish classes related to my career goals were set up this way'. Our task is to refine the learning objectives and pedagogical strategies central to this course and others like it so that the long-term, professional value of learning across the human rights and STEM divide becomes ever clearer. 